СУЧАСНА СИСТЕМА МІЖНАРОДНОГО ПРАВА

\title{
EU LEGAL REGULATION OF COMPETITION IN INNOVATIVE MARKETS
}

\author{
ПРАВОВЕ РЕГУЛЮВАННЯ КОНКУРЕНЦІї В ЄС НА \\ ІННОВАЦІЙНИХ РИНКАХ
}

\section{ПРАВОВОЕ РЕГУЛИРОВАНИЕ КОНКУРЕНЦИИ В ЕС НА ИННОВАЦИОННЫХ РЫНКАХ}

\section{Smyrnova K.}

Dr. of Jur. Sc. (Dr.hab.), Professor, Chair of Comparative and European Law, Institute of International Relations, Taras Shevchenko National University of Kyiv. E-mail: ksenya.smyrnova@gmail.com

\section{Смирнова К.В.}

Доктор юридичних наук, доцент, професор кафедри порівняльного і європейського права, Інститут міжнародних відносин Київського національного університету імені Тараса Шевченка. E-mail: ksenya.smyrnova@gmail.com

\section{Смирнова К.В.}

Доктор юридических наук, доцент, профессор кафедры сравнительного и европейского права, Институт международных отношений Киевского национального университета имени Тараса Шевченко. E-mail: ksenya.smyrnova@gmail.com

Abstract._The digital world is highly dynamic. The only way of survival is to keep innovating, in some extend even invent a way (legal or illegal) to secure its position. As this new phenomenon becomes increasingly sophisticated, the need for laws to govern it becomes more poignant. In consequence, the European Union has taken various actions towards realizing this aim of regulating the digital platform horizon. The evolutionary development of active \& passive selling through new electronic or other innovative means which is currently erases national borders leads to the comprehensive involvement of different national competition regimes. The competition authority has kept close scrutinizing on those firms in dominant position in their relevant market. Not only this, as the digital market is mostly multiple sided, the interaction between market are also taking care. However, the competition laws should adapt in the proactively to prevent the anti-competitive measures. The competition authority needs to have the anticipation on the dynamic evolution of competition in digital market and act proactively. Thus the most crucial aspect is to balance the innovative progress \& the necessity to control on competition. This article examines how the nature and logic of competition law changes as authorities expand the time horizon that they consider in their prospective analysis.

Key words:_digitalization, competition law, abuse of dominant position, exploitative abuse, e-commerce, vertical agreements

Анотація. Цифровий світ дуже динамічний. Сдиний спосіб виживання - це продовжувати інновації, в деяких випадках навіть винаходити шлях (законний чи незаконний) для забезпечення своєї позиції. Оскільки це нове явище стає дедалі складнішим, потреба у правовому регулювання цієї сфери стає більш гострою. Внаслідок цього Європейський Союз здійснив різні заходи щодо реалізації цієї мети регулювання горизонту цифрових платформ. Еволюційний розвиток активних та пасивних продажів за допомогою нових електронних або інших інноваційних засобів, 
які в даний час руйнує національні кордони, призводить до всебічного залучення різних національних конкурентних режимів. Конкурентні відомства уважно пильнують за тими суб'єктами, які мають домінуюче положення на відповідному ринку. Правила конкуренції мають активно адаптуватися, щоб запобігти порушенням. Таким чином, найбільш важливим аспектом є збалансованість інноваційного прогресу та необхідність контролювати конкуренцію. У цій статті розглядається, як змінюється сутність та логіка застосування правил конкуренції (на прикладі СС).

Ключові слова: цифралізація, конкуренційне право, зловживання домінуючим становищем, експлуататорське зловживання, електронна торгівля, вертикальні угоди.

Аннотация. Цифровой мир очень динамичен. Единственный способ выживания - это продолжать инновации, в некоторых случаях даже изобретать путь (законный или незаконный) для обеспечения своей позиции. Поскольку это новое явление становится все сложнее, потребность в правовом регулировании этой сферы становится более острой. В результате Европейский Союз осуществил различные мероприятия по реализации этой цели регулирования горизонта цифровых платформ. Эволюционное развитие активных и пассивных продаж с помощью новых электронных или иных инновационных средств, которые в настоящее время разрушает национальные границы, приводит к всестороннему привлечению различных национальных конкурентных режимов. Конкурентные ведомства внимательно следят за теми субъектами, которые имеют доминирующее положение на соответствующем рынке. Правила конкуренции должны активно адаптироваться, чтобы предотвратить нарушения. Таким образом, наиболее важным аспектом является сбалансированность инновационного прогресса и необходимость контролировать конкуренцию. В этой статье рассматривается, как меняется сущность и логика применения правил конкуренции (на примере ЕС).

Ключевые слова: цифрализация, конкурентное право, злоупотребление доминирующим положением, эксплуататорское злоупотребления, электронная торговля, вертикальные соглашения.

The current problem. The digitalisation has brought fundamentally change to daily life and business. It has also brought new cosmos to competition. The market competition structure was maintained from one balance to another. From the one hand competition in the market increases efficiencies and encourages and stimulates innovation. From another point trade liberalization process, extremely growth of innovations, new platforms for trading \& providing services influences the risk of anticompetitive behavior in the markets. Presently, within the EU, there is not a uniform legal regulatory framework specifically governing digital platforms. In principle, they are presently governed by standard and well-established EU rules relating to data protection, intellectual property, consumer protection, competition and intellectual property, etc. Competition law and consumer protection policies are complementary and mutually reinforcing. Thus the most crucial aspect is to balance the innovative progress \& the necessity to control on competition. EU experience in linking national competition regimes into supranational unified mechanism can be fruitful on the international level. That's why the second generation of international (bilateral/multilateral) agreements aimed on the closer cooperation of National Competition Authorities (NCAs) in their fact findings \& cooperation within investigations.

The evolutionary development of active \& passive selling through new electronic or other innovative means which is currently erases national borders leads to the comprehensive involvement of different national competition regimes. Simple active selling replaces innovative passive selling schemes through e-commerce, social networks or other ittechnologies. Microsoft case seems to become the only first step in the similar line cases. For instance, Google [1] \& Intel [2] illustrated well proved basis of anticompetitive conduct. 
Investigations on Alibaba \& Amazon [3] ought to represent more complicated analysis of trade measures \& their influence on competition.

NCAs should pay increasing attention to finding appropriate remedies for fair market $\&$ consumer protection. The legal debate on the best regulatory approach has often been framed in terms of different forms of regulation expressed by the dichotomies of regulatory diversity versus regulatory harmonisation or regulatory competition versus regulatory cooperation. The European economic policy tends to limit the incentives and capacities to invest in new technologies and in fixed assets that incorporate those technologies. Such a policy hampers dynamic efficiencies by impeding expected profit margins which are needed to sustain current and future investments.

The aim of the article is to analyze the experience and peculiarities of legal regulation in innovative market, e-commerce due to the process of digitalization.

\section{Analysis of the latest publications.}

Granieri and Renda [4] give the following definition: (a) the creation of new (or the efficient reallocation of existing) resources (b) which contribute to progress. The first, ontological, element of innovation is approached in the broadest possible sense, leaving space for usergenerated innovation, automated innovation, industrial $R \& D$ projects, public investment, etc. The second, teleological, element simply states that a new product is to be considered innovation only to the extent that it contributes to social welfare in the long run, without depriving society of resources that could have been more usefully allocated elsewhere. In a nutshell, innovation's main features are allocative efficiency and progress. The OECD (2005) distinguishes between four types of innovation: product innovation, process innovation, marketing innovation and organizational innovation. Another very important distinction in the economic literature is that between disruptive (or "radical") and incremental (or "followon") innovation. Campbell, R.W. [5] analyzed innovation markets of the US. Awrey, D. [6] continued to analyze competition rules in the financial markets. Bekkers, R., G. Duysters and B. Verspagen [7] focused on intellectual property rights \& its influence on competition. Belleflamme, Paul and Cecilia Vergari [8] provided analysis of oligolistic markets.

What is problematic from a legal standpoint is the introduction of the dynamic dimension of innovation in the analysis, that is, of innovation-related arguments that are yet to materialized when administrative action takes place.

The important research results. There are several legal regimes that can be used in competition cases depends on the shares on relevant market - whether anticompetitive agreements \& restraints or abuse of dominant position can be applied.

Online trade in goods and services (referred as e-commerce) can be divided into three basic fields. A distinction needs to be made in terms of trade between companies (business-tobusiness - B2B), that between companies and consumers (business-to-consumer- B2C), and between consumers (consumer-to-consumer - C2C). The trading "places" are named "online trading platforms" or "online market places".

Nowadays, most of the business has their own website, on which they place companies' introduction and products information. Now the website is also used for transactions. It has become a part of many companies and consumers in the past 10 years. Ecommerce has its advantages, such as it largely saves the cost of supplier, provide the consumers of the possibility to compare the products and getting the producers closer to the consumers, etc. however, has also disadvantage. It poses challenges for classical brick-andmortar trade in particular, which faces falling visitor numbers. In some cases this has given rise to the fear that city centres may die out. Moreover, transport cost, quality issue as well as intellectual property rights are all part of the concerns.

E-commerce affects commercial competition in a number of ways. The possibility to enter the market varies from one market segment to the next. While trading platforms in particular make it easier for online dealers to enter the market, they can be professional retailers or individuals. Ultimately, therefore, the development of e-commerce not only 
intensified the competition between goods and service providers, it also created the rivalry between different e-commerce platform, such as eBay and Amazon.

In e-commerce, there are two major types of players. First, the platform providers, such as Amazon, eBay or Alibaba. At the beginning of e-commerce, they usually provide only "marketplace" in which other vendors and buyers "meet" and make transaction. Unlike traditional marketplace, many transactions are concluded based on description, photos and reviews only. And the payment shall be made in advance. Sometimes, there is possibility to see and examine the goods, when vendor and buyer are not far-away.

The competition between platforms is intensified on the quality and variety of service they provide to users. The value of each online business depends a lot on the quantity of users they have. Therefore, in e-commerce, as platform providers, their potential competition issues are also possible users" "lock-in effect". As there is no easy solution for vendors to change from one platform to another without baring transfer cost, i.e. from eBay to Amazon, the vendors simply place their goods on both platforms. On the other hand, the Platform provider such as Amazon has its own products for sale. Consequently, bundling and preferential treatment of services belonging to the platform may happen.

Among other players, there other types of anti-competitive conduct may happen. As ecommerce is just a place where seller and buyer meet, communicate and/or transact, all the anti-competitive practices which happen in the 'real' business word may happen also online.

The traditional competition law concerns that are generally associated with vertical restraints are (i) the risk of facilitating collusion and (ii) the risk of hindering competition. These anticompetitive motivations for firms to engage in vertical restraints apply equally to ecommerce. In particular, there are situations where the imposition of vertical restraints like resale price maintenance (RPM) will reduce competition between brands and therefore harm consumers [9, p. 180-183].

However, regarding the RPM, some arguments saying that "there is already a lot of price transparency in this environment and thus vertical restraints cannot act as a way to make it easier to enforce the collusive output of a cartel. Therefore there should be fewer reasons for concerns from RPMs in an online environment".

A vertical agreement between a manufacturer and a distributor can affect competition in two distinct markets: the upstream market where the manufacturer competes with similar firms and the downstream market where retailers compete against other retailers. The former type of competition is called "inter-brand" competition as it occurs among various suppliers whose products are mainly identified through the use of specific brands. Downstream competition may also occur among retailers who sell the products of the same manufacturer; this form of competition is called "intra-brand" competition. It is generally believed that a reduction of intra-brand competition is unlikely to harm consumers if there is a strong interbrand competition. For instance, the European Commission Guidelines on Vertical Restraints states that "if inter-brand competition is fierce, it is unlikely that a reduction of intra-brand competition will have negative effects for consumers" (par. 102) [10]. The reason why interbrand competition is deemed to have a stronger impact than intra-brand competition on consumer welfare hinges on two considerations. First, consumers derive most of their welfare from the characteristics of the products they consume and inter-brand competition guarantees that manufacturers will strive to innovate their products and to choose the features that meet consumers' preferences. Second, manufactures will also compete by offering consumers the lowest possible price; since consumers pay the retail price, they seem to have no reasons to limit price competition among their own retailers, unless this is the only way to induce retailers to provide ancillary services or to invest in promotional activities that benefit consumers more than a limited price reduction.

An example is the EU decision dated 4 May 2017 [3], which adopts commitments from Amazon not to enforce unfair clauses which mandate publishers to offer Amazon similar or 
better conditions offered to competitors as well as disclose alternative terms offered to Amazon's competitors.

A general classification of vertical restraints distinguishes between: 1) price restraints and 2) non-price restraints.

The price related restrains are the measures which fix directly the resale price or impose obligations on the retailers to maintain their resale price not higher or not lower than certain level.

While the non-price constrains are more various [11]:

Exclusive distribution: whereby each distributor is allocated a specific territory or a specific group of customers to which it can actively sell its products.

Selective distribution: an agreement that restricts the number of authorised distributors based on selection qualitative criteria linked to the nature of the products and the complementary services that need to be provided to the buyers.

Single branding: an agreement that imposes on the buyer an obligation to procure a product of a given category from a single supplier; the same situation may arise with a "quantity forcing" obligation whereby the buyer is forced or induced to buy (or stock) a predetermined minimum volume of product so that it will de facto limit its purchases from one supplier.

Exclusive supply: an agreement whereby the supplier has an obligation to sell the relevant products to a single buyer; as in the previous case, the same effect can be obtained through some form of quantity forcing;

Tying and bundling: whereby a manufacturer conditions the purchase of one product (the tying product) to the purchase of a second product (the tied product); when the two products are sold in fixed proportions this practice is normally called bundling.

The foreclosure effect caused by Vertical restrains, especially in highly concentrated markets catches always the most attention of competition authorities. Entry can be prevented at all levels of the supply chain, likewise exit can be driven at any of the vertical stages. Some restrains that mimic vertical integration, such us exclusive dealing (both single branding and exclusive supply), may discourage potential entrants because they think that their access to the potential consumers are limited by the restrains, as a result they will decide not to enter the distribution chain and participate in the competition.

In the same way, such restraints may also drive some competitors out of the market, costs for competitors become too high for them to profitably remain in the market.

Some vertical restrains may have the effect of facilitating collusion either in the upstream or in the downstream market. In the upstream market collusion may be prevented if suppliers do not observe wholesale prices. Resale price maintenance agreements allow the possibility of manufacturers to detect deviations and thus facilitate collusion because they make retail price less dependent on retail costs. On the other hand, without price maintenance, the retailors have more motivation to reduce their distribution cost, improve quality of service and as a result to obtain customers' loyalty.

In downstream markets similar price arrangements, even if do not impose the retail price, may provide focal points to retailers and therefore increase their ability to coordinate on higher more profitable prices. Non-price restraints, such as exclusive distribution agreements, may similarly help distributors in sustaining a collusive equilibrium as they limit the scope for deviations from the collusive path.

While collusion indicates a dynamic phenomenon in which welfare reducing selling conditions are sustained through the threat of market punishments, competition may be softened also in static games by practices that lower firms' incentive to compete aggressively.

Vertical restraints may have a direct and straightforward effect of softening intrabrand competition. A manufacturer imposing price restraints (e.g. RPM) tends to reduce the effectiveness of competition among retailers; similarly, allocating exclusive territory rights to 
its distributors, the manufacturer induce monopoly power for each retailer in the given territory.

These practices can also soften inter-brand competition between manufacturers. Through an exclusive distribution system, the competitors are not engaged in effective competition therefore, a manufacturer may commit to price less aggressively and this, in turn, gives incentives to rival manufacturers to set higher prices.

The e-commerce platforms are geographically unlimited, however, they are limited in terms of language and sometimes culture. For example, French users may use ".fr" for their search, while for the American users, they use the same website but with ".com". The concerns may occur within the same firm which has their sale online within internal market.

The different languages in some sense obliged the seller to provide sales platform according countries' need, while it was also take as advantage to discriminate sales price within internal market. For goods, there may exist transport cost between different member state (justified discrepancy), while for services, such as hotel and flight tickets, the transport cost can be ignored, the price discrepancy between Member States become unreasonable.

A sample story on EU website shows that "as EU nationals, you cannot be charged a higher price than local residents when buying products or services anywhere else in the EU, unless the price difference is justified.

It seems in the situation of hotel or flight booking, the difference is unlikely to be justified. A Spanish who can speak French may take advantage of French price while if he doesn't speak French, he is discriminated.

This discrimination based on language barrier is, by fact, against EU internal market strategy. But in the Directive 2006/123/EC on Services in the internal market [12], it stipulates everywhere that the discrimination on grounds of nationality or nationals residence place is forbidden, while no clear guidelines on the "passive" discrimination on grounds of language. And clearly, many consumers are not informed enough in this situation.

According to digital single market strategy published in September 2016 [13], "European citizens face barriers when they use online services and tools. Online markets remain largely domestic: only $15 \%$ of citizens shop online from another EU country and as few as $7 \%$ of small and medium-sized businesses sell in another EU country..." Therefore, this strategy on one hand aims to increase the investment and growth of the business in digital market, on the other hand, aim to improve the accessibility of consumers to the cross border goods and services, in which, the delivery issue, VAT issue and the "geo-blocking" issue etc. will be included. The "discrimination" on language issue is likely remains.

Digitalisation has initiated profound structural changes that affect virtually all areas of life. Companies, consumers, politics, and society as a whole face new challenges in light of the ever growing use of digital services.

The challenge that competition law faces is, on one hand, to adapt the established legal framework to the new environment. All the regulations, Acts, etc. which apply and enforce on the practices in the "real" (offline) business shall apply to the practices to "virtual" (online) business; on the other hand, need to establish clear and well-spread regulations for users protections, as currently more and more users join the digital word while very few of them really are aware of their rights and/or when their rights might be violated.

The Internet indeed might be a powerful means to intensify rivalry between competitors and, in some cases, a positive drive of innovation on its own. But which of these practices have positive, which have negative effects on consumer and on market competition, depends on many other elements, such as, consumers' habits, specific characteristics of industry and market definition, etc. The formation of new general presumptions and the lack of knowledge of consumers obfuscate these differences and precludes the flexibility that therefore it is needed to adapt/adjust the application of competition rules to the specific circumstances of each case. 
It is concluded in the paper through several observations of the cases that the EU Competition Law shall evaluate in two major areas - vertical restraints \& abuse of dominant position.

The Article 102 of TFEU provided that "Any abuse by one or more undertakings of a dominant position within the internal market or in a substantial part of it shall be prohibited as incompatible with the internal market in so far as it may affect trade between Member States."

2 primary criteria were given: (1) the firm owns dominant position (meaning that $50 \%$ or plus market share); (2) the conduct is abusive. In addition, the Article 102 provided a list of conducts which might be considered "abusive".

(a) directly or indirectly imposing unfair purchase or selling prices or other unfair trading conditions;

(b) limiting production, markets or technical development to the prejudice of consumers;

(c) applying dissimilar conditions to equivalent transactions with other trading parties, thereby placing them at a competitive disadvantage;

(d) making the conclusion of contracts subject to acceptance by the other parties of supplementary obligations which, by their nature or according to commercial usage, have no connection with the subject of such contracts.

According to the European case-law, in order to identify an abuse, it must be generally examined whether a company that is in a dominant position has engaged in: "behaviour [...] which is such as to influence the structure of a market where, as a result of the very presence of the undertaking in question, the degree of competition is weakened and which, through recourse to methods different from those which condition normal competition in products or services on the basis of the transactions of commercial operators, has the effect of hindering the maintenance of the degree of competition still existing in the market or the growth of that competition" [14].

This definition of abuse largely consists of two elements. First, the market structure must already have been weakened because of the presence of the undertaking in question (dominance). Second, the undertaking must engage in conduct which differs from normal competition and additionally restricts competition.

The above definition of abuse is largely concerned with the question of whether it is sufficient that the conduct of the undertaking in question can have a competition-restricting impact, or whether this in fact must be proven. The case-law has made it clear that it is sufficient for the conduct to potentially have a competition-restricting impact [15].

Moreover, it should be noted that EU competition authority will not take measures to forbid the abusive conducts when apply Article 102 of TFEU. There is another element in the decision making, which is that whether the market and other competitors may positively and effectively react regarding this abusive conduct and to offset the negative effect caused by the dominant company. It is of course logical that the competition authority won't over-protect the competition at the cost of innovation. The improvement can be made only under competitive environment. If the companies at the weaker position rely always on protection of competition law, then it is more likely that they improve less and lose the competitiveness after some time. Especially the digital market is defined high dynamic and innovative. For instance, if the market is divided by 4 companies A, B, C, D with the market share $50 \%, 20 \%$, $25 \%$ and $5 \%$. If company $A$ (the one in dominant position) conducted certain practice, company B, C, D cannot either individually or jointly find the countermeasure to react against the conduct, then the competition authority shall react. In this situation, the company B, C, D still have disputable market power. While in the case of Microsoft, which has more than $90 \%$ market share in OS market, no other competitors is disputable against its abusive conduct. Here comes the question. When we define the dominance, it is general $50 \%$ or more market share. However, companies with 50\% market share has certainly different market power compare to company with $70 \%$ market share, and of course present different effects. In the 
first case, there is chance that the market competition can be maintained or rebalanced, while in the second case, it is very unlikely. Therefore this situation would be better if they are examine by law separately. For example, if the definition of abuse conducted by dominant which has $70 \%$ market share, the conduct is per se forbidden. In addition, the efficiency defence shall be inutile.

The advantage of this refining in terms of dominance is that (1) the competition authority may shorten their proceeding time based on the significance of dominance and the fact which is abusive; (2) the dominant company will restrain on their conducts which fall in the Article 102, as there will be no efficiency defence.

As the digital market is very dynamic and has become complex due to the development of $\mathrm{N}$-sided market, there may need some additional legal framework to enhance the anti-competitive enforcement. The condition of the existence of market dominance also appears to be appropriate in the digital economy. However, the characteristics relating to events on the market should be taken into account when identifying market power.

The examination standard does not explicitly accommodate the characteristics of multi-sided platforms which is one of the strongest character and trend of digital market. However, it is likely to regard the criteria to be examined authoritative if they indicate market dominance on the respective sub-market (e.g. search engine market) in an overall assessment of all interdependent sides of the platform. It should be presumed as well that the loyalty of the users on one side of the platform can expand the scope of conduct available to the platform users of a multi-sided platform on other sides of the platform (e.g. in the case of Google: Google+ and advertising markets).

Conversely, if the users on one side of the platform (e.g. in the case of Google: content providers and advertiser) can limit the reaction of the platform users on an interdependent further side of the platform (e.g. in the case of Google: the search engine markets). In addition, the dynamic nature of digital markets is facilitating market dominance as companies can recognise and react promptly to changes in demand at an early stage, so that they can prevent their market dominant power being damaged. This is the reason why the current market dominance situation in one sub market or in one independent side of $\mathrm{N}$-sided market is unlikely to change. Such as Google in searching engine [16], Microsoft in OS, Facebook in social network.

However, these dominant companies can use their competitive advantage in one side of the market (e.g. Google in searching engine) to leverage the competition in other market (e.g. Google docs). In some sense it is positive because it may be regarded as new opening of the previously unbeatable dominance. For example, Microsoft Office was in absolute dominant position for about 25 years. It is still in dominance today [17; 18]. The development of Google Doc, and other OpenOffice certainly favour the competition in the Open Document market. If Google use its power in other side of market to leverage the competition in Open Document market, the measures are unlikely to be forbidden. While conversely, if Google use its power in searching engine market to hinder the competition in tablet (Google device) or mobile system (Android) competition, these kind of measures shall be prohibited.

The usual market definition was given by European Commission in the commission notice. "A relevant product market comprises all those products and / or services which are regarded as interchangeable or substitutable by the consumer, by reason of the products' characteristics, their prices and their intended use." [19]

It examines the substitution relation between products in competition, while hasn't touched the multi-sided market. When facing the examination of market complexity in digital economy, it cannot meet the need and may result in dispute between parties in dispute. Therefore, the definition of markets and examination of abusive conducts which cross different market sides and involve different products, shall be improved.

Special attention should be paid to the characteristics of multi-sided platforms, especially these platform may vary with digital development (dynamic nature). Such query is 
necessary, for example, for Ads industry, the search based and non-search based (display) advertising, or desktop and mobile advertising, since technical improvements have caused these forms of advertising to become more similar. Addition attention should be paid to possible substitution relationships between online and offline advertising.

Except the foreclosure effect (exclusionary abuse), there exist another type of abuse which is closely related to the digital life and digital users. The exploitation of third-party content and data constitutes competition-relevant conducts. It has three major concerns. The copy right issue, the privacy protection and consumers' right protection. These three aspects are recognised as non-antitrust law related, however are closely linked to market competition as the violation may either detriment the active competition or enhance companies' market position.

Existing copyrights, the rules of fair competition and the privacy rules can be violated by - among other things - commercial operations on the internet. Companies with market power can use this kind of conduct to enhance their market position.

The following is a non-exhausted list of violation conducts:

- displaying protected content of books/images in vertical search results or in social networks (breach of copyright or related rights);

- the collection of personal data by providers of internet services (search engines, social networks, trading platforms), but also for instance automatic price differentiation in internet offers (breach of privacy regulations);

- $\quad$ emulation of competing services/ products (copyright issue)

- $\quad$ deceptive information provided online

- $\quad$ misleading display of search results by search engine operators to re-direct data traffic (breach of the Unfair Competition Act). effect/foreclosure)

- Increase barrier of retrieve for platform or network users (lock-in

Such violations of the law are constantly observed by the European Commission in recent years with the active player in the digital market. Abuses of market power by violating non-antitrust law have so far only been rarely examined in the European case-law as they are regulated by International Property Law, Privacy regulations and Consumer Protection Act (different countries may have different nomination of law) respectively. It is recognised that EU law only protects performance-based competition and that a company may not abuse its dominant position by gaining an advantage through unlawful and deceptive acts which make it possible to exclude from application of competition law.

The use of unlawful contractual provisions may also be abusive in other cases, at least if it is an expression of market power or of considerable market superiority on the part of the user. Legally recognised rights may also restrict the scope of conduct for a dominant company. Hence, the violation of such rights may also be abusive within the meaning of antitrust law.

On the other hand, besides the improvement of regulation, the players' education shall be available. In many case, most of dominant company were reading / interpreting the antitrust law in their way and thus tried to find the ambiguous area which is not covered by the law text. Therefore, if there is no change on current law text, there should be at least clear guidelines on application of competition law in digital market.

Regarding users right protection, it is conceivable given such abuses of market power that they additionally show exploitative elements, such as in the case of the exploitation of third-party content and data (if this takes place to the disadvantage of content-providers and data owners) or in the case of specific prevention of customer switching (e.g., excessive binding of customers by restricting data portability).

On platform markets, the extent to which this potential for legal abuse exists is essentially influenced by the dynamic nature of the market development and by the characteristics of the platform (e.g., the extent of data access, the kind of network effects). 
The European General Data Protection Regulation should make a major contribution towards reducing competition distortions. This Regulation will, as EU competition law, have extra-territorial application. The data portability rights provided for in the Proposal can help stimulate competition, as they mitigate existing barriers to users' switching (lock-in effects).

Conclusions. Taking into account the digitalisation does not release the work of competition authorities. In the contrary, except traditional market, competition authorities need to take care anti-competitive measures origination in digital market. Such as whether there is consumer's lock-in effect, whether there is exclusive effect. In one word, all the anticompetitive measures identified by competition authorities may also happen in digital world. However, whether the current competition laws are suitable or strong enough to prevent those measures which may harm consumers' welfare? Whether the current competition laws adapt well to the digital market so that the law enforcers can have enough legal frameworks to judge each measure? What is the future of digitalisation and its impact on competition? There are several legal regimes that can be used in competition cases depends on the shares on relevant market - whether anticompetitive agreements \& restraints or abuse of dominant position can be applied.

The most crucial aspect is to balance the innovative progress \& the necessity to control on competition. EU experience in linking national competition regimes into supranational unified mechanism can be fruitful on the international level. The ways of doing business become different. Paper era is almost being replaced by different kind of digital substitution. Therefore, it is very interesting to look into the market behaviours of the companies and discover the change of competition law itself with the time. For example, the famous Microsoft case on its bundling of media player (2004) was ruled illegal, while the same behaviour - Skype bundling (2013), was ruled differently. Then it is necessary to understand, why the EU Commission has made different ruling within 10 years and what are the reasons that have made them to do so. In 10 years, digital market is able to make a big change, so should the competition law and of course, consumers' perception on both competition law and various measures in digital market.

The digital world is highly dynamic. The only way of survival is to keep innovating, in some extend even invent a way (legal or illegal) to secure its position. Therefore, the order of the market, as well as its dynamic nature shall be maintained. The competition authority has kept close scrutinizing on those firms in dominant position in their relevant market. Not only this, as the digital market is mostly multiple sided, the interaction between market are also taking care. However, the competition laws should adapt in the proactively to prevent the anti-competitive measures.

\section{References}

1. Google/Motorola Mobility (Case COMP/M.6381) Commission Decision of 13 February 2012 [2012] C75/1.

2. Intel (Case COMP/C-3/37.990) Commission Decision of 13 May 2009 [2009] C227/13.

3. Final European Commission commitments Case COMP/AT.40.153 E-book MFNs \& related matters http://ec.europa.eu/competition/antitrust/cases/dec_docs/40153/40153 4393_3.pdf

4. Granieri, M. and A. Renda (2012), Innovation Law and Policy in the European Union, Milan:Springer.

5. Campbell, R.W. (2012), "Rethinking Regulation and Innovation in the US Legal Services Market", New York University Journal of Law and Business, Vol. 9, No. 1, pp. 1-70.

6. Awrey, D. (2012), "Complexity, Innovation, and the Regulation of Modern Financial Markets", Harvard Business Law Review, Vol. 2, No. 2, pp. 235-294. 
7. Bekkers, R., G. Duysters and B. Verspagen (2002), "Intellectual Property Rights, Strategic Agreements and Market Structure: the Case of GSM", Research Policy, Vol. 31, No. 7, pp. 1141-1161.

8. [Belleflamme, Paul and Cecilia Vergari (2010) 'Incentives to innovate in oligopolies', The Manchester School 79(1): 6-28.

9. Handbook on European Competition Law. Substantive Aspects (2013) [ Ed. by Lianos I., Geradin D.]. - Cheltenham : Edward Elgar PublishingLimited: 665p.

10. Commission notice - Guidelines on Vertical Restraints /* SEC/2010/0411 final $10 / 05 / 2010$

11. [11] Smyrnova K. V. (2013) EU Competition Law: textbook with schemes \& case studies, Odesa : Feniks, 144 p.

12. Directive 2006/123/EC of the European Parliament and of the Council of 12 December 2006 on services in the internal market // OJ L 376, 27.12.2006, p. 3668

13. The European Commission's preliminary report on its e-commerce sector inquiry http://europa.eu/rapid/press-release_IP-16-3017_en.htm

14. Case 85/76 Hoffmann-La Roche \& Co. v. Commission // ECR [1979] 461.

15. Case T-201/04 - Microsoft // ECR [2007] II-2977

16. Google/Motorola Mobility (Case COMP/M.6381) Commission Decision of 13 February 2012 [2012] C75/1.

17. Microsoft (Tying) (Case COMP/39.530) Commission Decision of 16 December 2009 [2010] C36/7, para 104;

18. Case T-201/04, Microsoft Corp. v Commission [2007] ECR II-3601

19. Commission notice on the definition of the relevant market for the purposes of Community competition law (1997) OJ C 372, p. 5-13. 